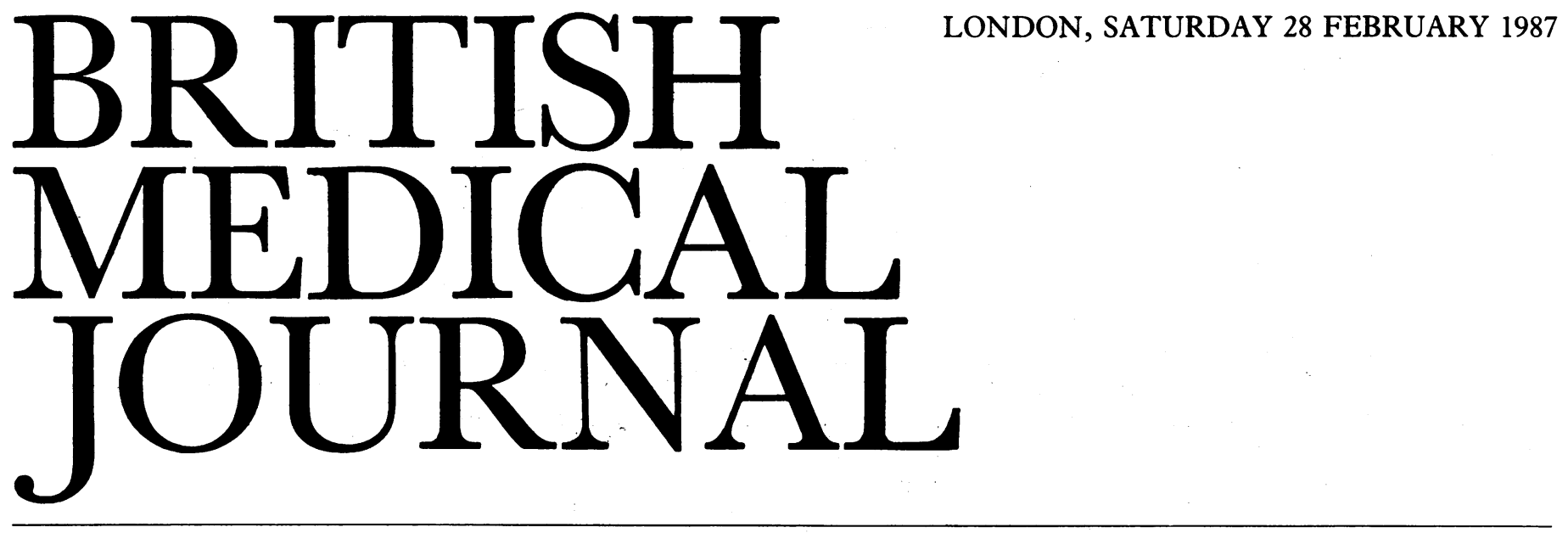

\title{
From New to old England: the progress of Lyme disease
}

Lyme, Old Lyme, and East Haddam are delightful small towns on the east bank of the Connecticut River. Many of the residents of these towns and of the surrounding areas are affected by a multisystem disease with chronic crippling sequelae.

Lyme disease is a seasonal infectious disease found in the United States, ${ }^{12}$ Europe, ${ }^{34}$ and Australia. ${ }^{5}$ Caused by the spirochete Borrelia burgdorferi, ${ }^{6}$ it is transmitted primarily by ixodes ticks; Ixodes dammini in the north east (Massachusetts to Maryland) and midwest (Wisconsin and Minnesota) ${ }^{178}$; $I$ pacificus in the western United States (California and Oregon $)^{9}$; and $I$ ricinus in Europe. ${ }^{10}$ The spirochete has also been isolated from horseflies and mosquitos and from many of its various animal hosts-that is, white tailed deer and raccoons.

Like other spirochetal infections the disease occurs in distinct stages. The usual initial manifestation, which occurs days to weeks after the spirochete enters the body, is a characteristic rapidly expanding erythematous rasherythema chronicum migrans. This lesion, often centring on the site of the tick bite, will be accompanied by multiple secondary lesions in as many as half the patients and a malar rash in $13 \% .{ }^{11}$ The skin lesions are often accompanied by malaise, fatigue, headache, fever, stiff neck, myalgias, arthralgias, or lymphadenopathy. Up to $10 \%$ of patients may have abdominal pain and vomiting, and these early complaints may be intermittent and changing. Initially $90-100 \%$ of infected patients reported having had erythema chronica migrans, ${ }^{11}$ but it is now apparent that some patients do not recall the tick bite or report a rash and present with other complaints, ${ }^{, 2} 13$ including disease of the nervous system and the heart and eventually chronic synovitis. These complaints may occur weeks to years after the tick bite.

About $15 \%$ of patients develop neurological problems. A unique triad of meningitis, cranial neuritis, and radiculoneuritis has been described, ${ }^{14}$ and $80 \%$ of neurologically affected patients developed meningitis and $70 \%$ encephalitis. Cranial neuropathies (most commonly facial palsy) and radiculoneuritis occur less often-in $55 \%$ and $45 \%$ of patients respectively. ${ }^{15}$ Findings in the cerebrospinal fluid include a lymphocytic pleocytosis and raised protein concentrations, and spirochetes have been isolated.$^{16}$

The first recent British report of neurological manifestations of Lyme disease ${ }^{17}$ has been quickly followed by a report of three more cases ( $p$ 548). As the authors comment, ixodes ticks are widespread in Britain and more cases may be seen soon. Bannwarth's syndrome (or tick borne meningopolyneuritis) has been known in Europe since the 1920s. Bannwarth recognised the association between the erythematous rash and neurological sequela ${ }^{18}$ but was unaware of a publication by Garin and Bujadoux that 19 years earlier had reported a tick bite leading to a spreading erythema, peripheral paresis, and meningitis. ${ }^{19}$

About $8 \%$ of patients develop heart problems, usually atrioventricular block. Cardiomegaly and diffuse cardiac damage have also been described, ${ }^{20}$ and spirochetes have been isolated from the myocardium of a patient dying with pancarditis. ${ }^{21}$ Arthritis occurs in about $60 \%$ of patient ${ }^{22}$ and usually begins months and sometimes years after the tick bite. Intermittent swelling of the large joints (especially the knees) may give way to chronic synovitis, with erosion of cartilage and bone in up to $10 \%$ of patients..$^{23}$ Examination of synovial biopsy specimens shows thickened inflammatory synovium infiltrated with lymphocytes and plasma cells, and obliterative microvascular lesions have been described in some patients. ${ }^{24}$ The synovial fluid is inflammatory, with polymorphonuclear leucocytes predominating. Spirochetes have now been identified in synovial fluid ${ }^{25}$ and around synovial blood vessels. ${ }^{24}$ The patients rarely produce rheumatoid or antinuclear factor. ${ }^{22}$

Laboratory testing for antibody reactive to spirochete has shown that specific IgM antibody titres rise to a peak between the third and sixth weeks after the onset of infection. Specific IgG antibody titres rise more slowly, and Steere reports that all patients with arthritis have raised IgG antibody titres..$^{1626}$ Severe Lyme disease has been shown to be associated with the B cell alloantigen DR2, a prolonged rise in serum $\operatorname{IgM}$ titres, and cryoglobulins containing IgM proteins. ${ }^{22} 27$

How these chronic complaints are caused is unknown. Is there continuing spirochetal infection or an abnormal immune response to a susceptible host? Hardin et al found circulating $\mathrm{Clq}$ binding material in nearly all patients at the onset of erythema chronicum migrans. In those who developed arthritis this material localised to affected joints, and the concentration increased with duration of joint inflammation and correlated positively with the number of synovial fluid polymorphonuclear leucocytes. ${ }^{28}$ These findings suggest that phlogistic immune complexes based on spirochetal antigens form locally within joints during chronic Lyme arthritis. 
Continuing infection is suggested as the cause by the isolation of spirochetes from cerebrospinal and synovial fluid, ${ }^{1525}$ the identification of spirochetes in synovium ${ }^{24}$ and myocardial tissues, ${ }^{21}$ and successful treatment of neurological ${ }^{29}$ and arthritic disease with high dose intravenous penicillin. ${ }^{30}$ Generally the yield of positive cultures has been very low: Steere et al investigated 118 patients, and only four specimens yielded spirochetes-23 specimens of joint fluid synovium and cartilage all gave negative results. ${ }^{31}$

Early treatment with antibiotics (tetracycline or penicillin) stops the disease's course. ${ }^{32} 33$ For adults the treatment is tetracycline ( $250 \mathrm{mg}$ four times daily for 10 days) and for children phenoxymethylpenicillin $(50 \mathrm{mg} / \mathrm{kg}$ daily in divided doses). None of 39 patients treated with tetracycline developed late complications of the disease compared with $8 \%$ of those given penicillin and $14 \%$ given erythromycin. ${ }^{33}$

Here in Connecticut the spirochete is progressing relentlessly up the Connecticut River valley into the heart of the state. In 1985 the state health laboratory recorded 863 new cases, and those of us in practice here see more cases each year. The rapid reporting of four cases in Britain shows that Lyme disease has now arrived in old England, too, and the disease may spread just as relentlessly.

ANN PARKe

Assistant Professor,

Division of Rheumatology,

University of Connecticut,

Farmington,

Connecticut 06032-9984,

USA

1 Steere AC, Malawista SE. Cases of Lyme disease in the United States: locations correlated with the distribution of Ixodes dammini. Ann Intern Med 1979;91:730-3.

2 Centers for Disease Control. Lyme disease. MMWR 1982;31:367-8.

3 Ackermann R, Runne U, Klenk W, et al. Erythema chronicum migrans mit Arthritis. Disch Med Wochenschr 1980;105:1779-81.

4 Illouz G, Hewitt J. A propos de l'athrite de Lyme: polyarthrite inflammatoire après un erythème annulaire migrant. Revue du Rheumatisme 1981;48:813-5.

5 Stewart A, Glass J, Patal A, Watt G, Cripps A, Clancy R. Lyme arthritis in the Hunter Valley. Med F Aust 1982; ;: 139 .

6 Johnson RC, Schmid GP, Hyde FW, Steigerwalt AG, Brenner DJ. Barrelia burgdorferi sp nov: etiologic agent of Lyme disease. International fournal of Systemic Bacteriology 1984;34:496-7.

7 Steere AC, Broderick TE, Malawista SE. Erythema chronicum migrans and Lyme arthritis: epidemiologic evidence for a tick vector. Am J Epidemiol 1978;108:312-21.

8 Wallis RC, Brown SE, Kloter KO, et al. Erythema chronicum migrans and Lyme arthritis: field study of ticks. Am J Epidemiol 1978;108:322-7.

9 Burgdorfer W, Kierans JE. Ticks and Lyme disease in the United States. Ann Intern Med 1983;99:121.

10. Barbour AG, Burgdorfer W, Hayes SF, Peter O, Aeschlimann A. Isolation of cultivable spirochete from Ixodes ricinus ticks of Switzerland. Current Microbiology 1983;8:123-6.

11 Steere AC, Bartenhagen NH, Craft JE, et al. The early clinical manifestations of Lyme disease. Ann Intern Med 1983;99:76-82.

12 Reik L Jr, Burgdorfer W, Donaldson JO. Nuerological abnormalities in Lyme disease without erythema chronicum migrans. Am $\mathcal{F}$ Med 1986;81:73-8.

13 Pachner AR, Steere AC. Neurological findings of Lyme disease. Yale J Biol Med 1984;57:481-3.

14 Pachener AR, Steere AC. The triad of neurological manifestations of Lyme disease: meningitis, cranial neuritis, and radiculoneuritis. Neurology $(N Y)$ 1985;35:47-53.

15 Reik L, Steere AC, Bartenhagen NH, Shope RE, Malawista SE. Neurological abnormalities of Lyme disease. Medicine (Baltimore) 1979;58:281-94.

16 Steere AC, Grodzicki RL, Kornblatt AN, et al. The spirochetal etiology of Lyme disease. N Englf Med 1983;308:733-40

17 Williams D, Rolles CJ, White JE. Lyme disease in a Hampshire child-medical curiosity or beginning of an epidemic. BrMed f 1986;292:1560-1.

18 Bannwarth A. Chronische lymphozytare Meningitis, entzündiche Polyneuritis und Rheumatismus. Archiv für Psychiatrie und Nervenkrankheiten 1941;113:284-376.

19 Garin CH, Bujadoux. Paralysie par les tique. Journal de Medecine de Lyon 1922;71:765-7.

20 Steere AC, Malawista SE. Lyme disease. In: Kelly WN, Harris ED Jr, Ruddy S, eds. Textbook of rheumatology. Philadelphia: W B Saunders, 1985:1557-63.

21 Marcus LC, Steere AC, Duray PH, Anderson AE, Mahoney EB. Fatal pancarditis in a patient with coexistent Lyme disease and babesoisis. Ann Intern Med 1985;103:374-6.

22 Steere AC, Malawista SE, Hardin JA, Ruddy S, Askenase PW, Andiman WA. Erythema chronicum migrans and Lyme arthritis: the enlarging clinical spectrum. Ann Intern Med 1977;86:685-98.

23 Steere AC, Brinckerhoff CE, Miller DJ, et al. Elevated levels of collagenase and prostaglandin E2 from synovium associated with erosion of cartilage and bone in a patient with chronic Lyme arthritis. Arthritis Rheum 1980;23:591-9.

24 Johnson YE, Duray PH, Steere AC, et al. Lyme arthritis: spirochetes found in synovial microangiopathic lesions. Am f Pathol 1985;118:26-34.

25 Snydman DR, Schenkein DP, Berardi BP, Lastavica CC, Pariser KM. Borrelia burgdorferi in joint fluid in chronic Lyme arthritis. Ann Intern Med 1986;104:798-800.

26 Craft JE, Grodzicki RL, Steere AC. The antibody response in Lyme disease: evaluation of diagnostic tests. I Infect Dis 1984;149:789-95.

27 Steere AC, Hardin JA, Malowista SE. Erythema chronicum migrans and Lyme arthritis: cryoimmunoglobulins and clinical activity of skin and joint. Science 1977;196:1121-2.

28 Hardin JA, Steere AC, Malawista SE. The pathogenesis of arthritis in Lyme disease: humoral immune responses and the role of intra-articular immune complexes. Yale $\mathcal{f}$ Biol Med 1984;57:589-93.
29 Steere AC, Pachner AR, Malawista SE. Neurological abnormalities of Lyme disease: successful treatment with high-dose intravenous penicillin. Ann Intern Med 1983;99:767-72.

30 Steere AC, Green J, Schoen RT, et al. Successful parenteral penicillin therapy of established Lyme arthritis. $N$ Englf Med 1985;312:869-74.

31 Steere AC, Grodzicki RL, Craft JE, Manesh Shrestha, Kornblatt AN, Malawista SE. Recovery o Lyme disease spirochetes from patients. Yale f Biol Med 1984;57:557-60.

32 Steere AC, Malawista SE, Newman JH, et al. Antibiotic therapy in Lyme disease. Ann Intern Med 1980;93:1-8.

33 Steere AC, Hutchinson GJ, Rahn DW, et al. Treatment of early manifestation of Lyme diseases. Ann Intern Med 1983;99:22-6.

\section{Continued medical education must not be an optional extra}

Clinical tutors working in postgraduate medical centres antedate the paid regional and associate advisers, course organisers, and trainers who run vocational training for general practice. Yet, as Berrington and Varnham report (p 550), general practitioners who are clinical tutors receive little payment and support. Consequently, they cannot devote much time to the important work of continued education - most did only two hours or less a week. This may partly explain why fewer than half of general practitioners attend, or claim expenses for attending, any postgraduate education each year.

Yet general practice is changing fast. Health promotion and the long term care of patients with chronic diseases are becoming much more important, and the number of elderly people in the community is increasing rapidly. New technologies and treatments are being introduced, and new patterns of teamwork are being adopted. At the same time there are increasing demands for economy and accountability, particularly in prescribing, arranging for investigations, and, above all, referring for secondary care. General practitioners will meet these challenges only through new methods of postgraduate education, with performance review as a cornerstone.

The standard of care offered by a doctor is related less to his or her knowledge than to factors that affect its application, ${ }^{2}$ and the most important of these is motivation. Doctors need to know what they are trying to do and how well they are doing it to maintain their enthusiasm; otherwise they develop rituals and their performance declines. ${ }^{3}$ Performance review means setting goals, assessing performance, and receiving and responding to feedback. It is difficult to be both self critical and self confident as a practitioner. Peer review is an opportunity to compare yourself with your colleagues, receive their support, and learn from their ideas, and the process has been shown to produce positive changes in practice. ${ }^{4}$

Performance review can form the basis of a curriculum for continued education but will be useful only if all the important aspects of practice are included and not just those that are easily measured-for instance, record keeping. Current controversies may unfortunately be obscuring the educational value of such powerful approaches as the practice assessment visiting recommended in the Royal College of General Practitioners' report What Sort of Doctor?. ${ }^{5}$ Basing education on the practice diminishes the feeling that it is something separate from work, and working with the whole practice team allows members to learn from each other and increases their commitment to change. ${ }^{6}$ The trend to educate in the practice is growing, ${ }^{7}$ and a range of resources are available to foster it, including distance learning materials and practice facilitators. ${ }^{8}$ 